\title{
Bentham's Concept of Security in a Global Context: The Pannomion and the Public Opinion Tribunal as a Universal Plan MICHIHIRO KAINO \\ Doshisha University
}

\section{Introduction}

Bentham is known as a pioneer of utilitarianism and legal positivism. But it is less well known that he aspired, through his life work, to be the legislator of the world. He tried to invent a complete code of laws - a 'Pannomion' -- which could be applied universally. Then he proposed that the USA, Russia, Spain, Portugal, Greece and Latin America should adopt his Pannomion. Indeed, in 1822, the newborn Portuguese government decided to adopt it. As that Portuguese government was overthrown in 1823, Bentham's dream, in the end, did not come true. But I think bringing to light Bentham's aspect as 'the legislator of the world' has a contemporary significance and is useful in discussing such currently important themes as law and justice in a global society. There are several reasons for this.

Firstly, we currently face problems of how to respond to the tides of globalization. As John Gray argues, many problems have stemmed (and are stemming) from imposing a universal system without regard to the social systems, cultures and religions of different countries. ${ }^{1}$ And these sorts of problems are a source of many of the possible counterarguments to Bentham's plan. These counter-arguments may be, for example, from the historical school of Savigny or cultural pluralism, which argues the relativity of values. But Bentham was aware of the importance of thinkers like Lord Kames, who emphasized the historical, social aspects of legal study, and Montesquieu, who may be the founder of legal and social studies. Bentham did think that it was necessary to change his Pannom ion according to the circumstances of the relevant country. In this paper, I want to examine Bentham's 'sensitive' attitude towards cultural diversity through his work 'Of the Influence of Time and Place in Matters of Legislation'.

Secondly, the discussion of cultural pluralism, the opposite pole of globalization, can also gain many insights from examination of Bentham's theory. It is generally argued that

\footnotetext{
${ }^{1}$ Cf. J. Gray, False Dawn: The Delusion of Global Capitali sm, London, 1998.
} 
responding to problems of modern society such as tyrannies or religious oppression is difficult from the perspective of cultural pluralism. Bentham himself praised the works of Montesquieu but criticized him for not separating matters of fact and matters of right. In 'Of the Influence of Time and Place in Matters of Legislation', Bentham divided the elements of cultural diversity into physical ones such as those that arise from climate, temperature and so forth and moral ones (such as those that arise from government, religion, culture and so forth). And as to the latter, which includes tyrannies, Bentham thought that from the standpoint of utilitarianism it could be shown that a change was necessary. Bentham developed an account of how to change these 'moral prejudices' of tyranny in his work 'Securities Against Misrule' and I want to discuss this work as well.

Thus, Bentham's position might be midway between 'globalization' and 'cultural pluralism'. And the key concept here is public opinion. When Bentham tried to change the moral prejudices of relevant countries, he emphasized the importance of the public opinion tribunal, which reflects the perceived intensities of people's pleasures or pains. This point is relevant in recent Bentham studies. Fred Rosen argues that Bentham's principle of utility is conventional, not critical or abstract, and Jennifer Pitts points out the difference between Bentham and John Stuart Mill, who supported imperial rule in colonies. Bentham also emphasized the importance of public opinion for the sake of security. As will be shown in the following, he argued that security through the public opinion tribunal should be ensured all over the world. This approach, which is followed by modern utilitarians such as Peter Singer, is, I think, appealing in our time when there are many critics 'who believe that liberalism as standardly formulated places too little emphasis on questions of global or international political morality'. ${ }^{2}$

I want to argue the above themes as follows. In section 2 of my paper, I will firstly try to depict the general view of Bentham's Pannomion (section 2.1). It has some interesting implications for modern legal theory and theories of justice. Then I will summarize Bentham's aspect as the legislator of the world (2.2). Bentham's Pannomion was intended to be universal and Bentham was very eager to be accepted as the legislator of some country. In the next section (2.3), I will try to depict Bentham's position on cultural diversity through his work 'Of the Influence of Time and Place in Matters of Legislation'.

Bentham did not try to change all cultural diversities. What he tried to change were those arising from 'moral prejudice' (in Bentham's words), such as tyrannies or religious

\footnotetext{
${ }^{2}$ S. Scheffler,Boundaries and Allegiances: Problems of Justice and Responsibility in Liberal Thought, Oxford, 2001, p. 66.
} 
oppressions. In section 3.1, I will introduce Bentham's work 'Securities Against Misrule', in which he tried to introduce a constitutional charter or a representative democracy into Tripoli, and examine Bentham as a practical theorist. In 'Securities Against Misrule', Bentham's idea of the public opinion tribunal is also developed. His point was that every institution must be examined by public opinion, and, as I will show in section 3.2, he thought that even despots have good reasons to consider the intensities of people's pleasures or pains for that can enhance security. Then I will examine Bentham's ideas of democracy and international law.As Philip Schofield argues, Bentham ultimately thought that only democratic countries can accomplish 'the greatest happiness of the greatest number' and 'securities against misrule'.

In the conclusion, I will firstly show that the significance of Bentham's theory is understood well when we compare Bentham's stance towards cultural diversity with those of John Locke and John Stuart Mill. In a word, Bentham's position was to ensure the autonomy of the people of relevant countries. He thought that if every government established freedom of the press and of public discussion, every country would adopt his Pannom ion because it is beneficial for them. Then I will focus on Bentham's concept of security. Bentham and his contemporary utilitarian followers can, I think, develop more convincing theory relating to globalization than rights-based theories, which can be depicted as western-centralized.

\section{The legislator of the world}

\subsection{Bentham's Pannomion}

As is well known, it was his discontent with common law which led Bentham to struggle to construct a Pannom ion. Bentham's criticisms of common law are developed in such works as A Comment on the Commentaries, and can be summarized as follows. ${ }^{3}$ The first defect of common law that he pointed out was its retroactive nature. According to Bentham, people's rights and obligations in common law cannot be clarified till judgments are given. In common law, the law and the legal provisions were not the same thing, and because judgments were regarded just as evidences of common law, judges could overthrow judgments which were contrary to reason. For common lawyers, this device was useful, because it could enhance the common law to adapt to social change. But for Bentham it was harmful, because it gave judges so much discretion that common law was necessarily rendered uncertain. The other defect of common law that he pointed out was its excessive complexity.

\footnotetext{
${ }^{3}$ Cf. J. Bentham, A Comment on the Commentaries andA Fragment on Government, ed. J. H. Burns and H. L. A. Hart, London, 1977 (The Collected Works of Jeremy Bentham). Hereafter Comment (CW).
} 
According to Bentham, common law was 'a labyrinth without a clew'. Bentham's famous metaphor, 'dog law', comes from the mystifying nature of common law. The non-lawyer could not understand the bewildering procedure that resulted in frustration for many suitors. In summary, Bentham rejected common law because of its uncertainty and obscurity. This rejection came from his conception of the role of law, which was to coordinate social interaction and guide people's behaviour effectively by securing people's expectations. As was argued by Bentham in The Theory of Legislation, without security of expectation (or simply security), people cannot live the coherent and continuous lives which are essential for human happiness. And Bentham thought that people's expectations could be secured only by introducing his Pannomion.

At first, Bentham's solution to the problems caused by common law's uncertainty and obscurity was to provide definite rules by making digests. But, after the 1780 s, he completely broke with the English legal tradition, and began to construct the Pannom ion based on his original theory. ${ }^{5}$

As to the fundamental theories of the Pannomion, they are developed in Of Laws in General $(O L G)^{6}$ and chapter 16 of An Introduction to the Principles of Morals and Legislation (IPML). ${ }^{7}$ The fundamental theory of its form is developed in $O L G$ whereas that of its substance is developed in IPML.

$O L G$ was an analytical work and the main theme of it was the individuation of law. An individual law was a logical, ideal and intellectual law, which was not more or less than a complete law. Bentham, who endorsed the command theory of law, argued that every individual law must contain an imperative, criminal provision and that those laws with only civil provisions cannot have the nature and effects of laws without being connected with imperative provisions. ${ }^{8}$ For example, the provisions of property rights cannot have effects of law unless they are connected with imperative provisions which prohibit interferences with property without titles. And in the Pannom ion, references were made from every provision of the Civil Code to the corresponding provision of the Criminal Code.

On the other hand, the theme of chapter 16 of IPML was a division of offences. Bentham thought that a complete analysis of offences would be a complete explanation of legal

\footnotetext{
${ }^{4}$ Cf. M. Lobban, The Common Law and English Jurisprudence, 1760-1850, Oxford, 1991, p. 173.

${ }^{5}$ Cf. D. Lieberman, The Province of Legislation Determined, Cambridge, 1989, p. 265.

${ }^{6}$ Cf. J. Bentham, Of Laws in General $(C W)$, ed. H. L. A. Hart, London, 1970. Hereafter $O L G(C W)$.

${ }^{7}$ Cf. J. Bentham, An Introduction to the Principles of Morals and Legislation, ed. J. H. Burns and H. L. A. Hart, London, 1970 (The Collected Works of Jeremy Bentham). Hereafter IPML (CW).

${ }^{8} C f . O L G(C W)$, p. 234.
} 
matters because every individual law makes one offence. As the Pannomion comprised individual laws, Bentham could argue that if the division of offences is comprehensive, there will be no ommission in the code. Bentham divided offences into: (1) private offences; (2) selfregarding offences; (3) semi-public offences; and (4) public offences. Each of these was then further sub-divided ${ }^{9}$ (for example, private offences were divided into offences against person, property, condition and reputation). The device used for the division was bipartition ${ }^{10}$ and Bentham argued that a comprehensive division would be possible by this method.

The more concrete nature of the Pannom ion can be clarified from 'A General View of A Complete Code of Laws' in the Bowring edition and 'First Lines of a proposed Code of Law for any Nation compleat and rationalized', from Legislator of the World: Writings on Codification, Law and Education. ${ }^{11}$ Firstly, as to the composition, Bentham said that the Pannomion comprises the Constitutional Code, the Civil Code, the Criminal Code and the Procedure Codes. In the Civil Code, the rights for person, property, condition and reputation, which are given their effect by the sanctions of the Criminal Code, are distributed to the people. ${ }^{12}$ Some provisions of the Constitutional Code, having distributive character, are also sanctioned by the Criminal Code. In terms of promulgation, as was argued in 'A General View of A Complete Code of Laws', the Criminal Code precedes the Civil Code because the individual laws comprised the Criminal Code. But as Gerald Postema points out, ${ }^{13}$ Bentham was well aware of the distinction between the logical structure and the social role of law, and he argued in 'First Lines' that 'it is the Civil Code that applies more immediately to the common end in view viz. the greatest happiness of the greatest number: with relation to the Civil Code, taking the mass of its arrangements for an intermediate end, the matter of the penal code is but a means'. ${ }^{14}$ The reason for this statement may be that the expectation utility generated from the definition of social relation in the Civil Code is much more important than the original utility which is concerned with the Criminal Code. H. L.A. Hart's famous criticism of John Austin for overemphasizing the criminal aspect of law does not apply to Bentham.

As argued above, the purpose of Bentham's Pannomion was to secure people's legitimate expectations. Bentham's ultimate purpose was 'every man his own lawyer' and we can see his device for it in Legislator of the World. Firstly, as the maximization of the notoriety of law is

\footnotetext{
${ }^{9}$ Cf. IPML $(C W)$, ch. 16.

${ }^{10} C f$. Lieberman, p. 265. For a more contextual approach, $c f$.Lobban, Common Law, p. 161.

${ }^{11}$ Cf. J. Bentham, Legislator of the World: Writings on Codification, Law and Education, ed. P. Schofield and J.

Harris, Oxford, 1998 (CW). Hereafter Legislator of the World $(C W)$.

${ }^{12}$ Ibid., p. 237.

${ }^{13}$ Cf. G. Postema, Bentham and the Common Law Tradition, Oxford, 1986, pp. 181-3.

${ }^{14}$ Legislator of the World $(C W)$, p. 237.
} 
important for security of expectation, Bentham divided the whole Pannomion into general codes and particular codes to make it easier to memorize. The general codes are codes for people in general, and the Constitutional Code, the Civil Code, the Criminal Code and the Procedure Codes are included in this category. On the other hand, the particular codes are for particular classes of people. Bentham thought that by introducing particular codes it would be possible to reduce the amount of legal matter which people have to bear in mind so that the notoriety of law and expectation utility would be secured. ${ }^{15}$ Bentham's next device was to accomplish an all-comprehensive division of offences. ${ }^{16}$ The Pannomion has to be without blanks to secure expectations, but Bentham argued that this would be possible by a bipartition. Of course it is impossible to predict every offence, but as the classes of offences are clear, he thought it possible to respond to new offences so that expectations can be secured. Lastly, Bentham proposed that each provision of the Pannomion should be accompanied by justifying reasons. Pannomion was 'an uniformly apt and all-comprehensive law, accompanied with a perpetually interwoven rationale, drawn from the greatest happiness principle', ${ }^{17}$ and these reasons, Bentham thought, would secure people's expectations by making the provisions clear and restraining the deviations of judges and legislators. ${ }^{18}$

Although it is a familiar one, this may be the right place to assess John Rawls's criticism of Bentham, because the assessment can help to make the nature of Bentham's Pannomion clearer. As is well known, Rawls claimed that Bentham's theory is incompatible with liberal values as it can undermine minority rights. But, as Rosen points out, we have to see Bentham's theory not as a top-down theory but as a bottom-up theory in which not the principle of utility but the secondary principles derived from the principle of utility are applied to practice. ${ }^{19}$ Among these secondary principles are the security-providing principle and the disappointmentpreventing principle. The security-providing principle gives everyone rights of person, property, condition and reputation, which are not usually subject to a utility calculation. The greatest happiness of the greatest number cannot be achieved, Bentham thought, if we directly invoke the principle of utility and upset people's expectations. And as Paul Kelly suggests, these rights sanctioned by the provisions of the Pannomion could do the same jobs as Rawls's social primary goods by making the pursuit of diverse goods possible. ${ }^{20}$

\footnotetext{
${ }^{15}$ Cf. ibid., pp. 8-10.

${ }^{16}$ Cf.ibid.,p. 138.

${ }^{17}$ Ibid., p. 260.

${ }^{18}$ Cf. ibid., p. 249.

${ }^{19}$ Cf. F. Rosen, 'Utilitarianism and the Punishment of Innocent: The Origins of a False Doctrine', Utilitas, ix (1997).

${ }^{20}$ Cf. P. Kelly, Utilitarianism and Distributive Justice, Oxford, 1990, p. 87.
} 


\subsection{The legislator of the world}

It is a remarkable fact that Bentham's Pannomion was thought to be usable in any country if some adjustments were made according to the circumstances of that country. Bentham argued that 'in comparison of the universally-applying, the extent of the exclusively applying circumstances will be found inconsiderable' and actually proposed to many countries that they should adopt his codes. ${ }^{21}$ As I said in the introduction, this endeavour of Bentham's is not well known and Bentham studies have not paid much attention to it. But William Twining points out that Bentham's 'universal jurisprudence' is one of the five pillars of his jurisprudence (others being utility, the theory of fiction, legal positivism and the command theory, and democratic theory and constitutional law). ${ }^{22}$ And if we regard Bentham as a theorist of globalization', which I will do, it is useful to summarize Bentham's aspect of 'legislator of the world'.

Bentham firstly approached the United States of America. In 1811, he proposed to President Madison the adoption of his Civil and Criminal Codes, but he was declined in 1816. In 1814, he also approached the governor of Pennsylvania where some codification of the common law was underway. This proposal didn't succeed either, because of the indifference of the governor. So, Bentham changed his tactics and sent a circular to the governors of the United States. To this, there was a reply from William Plummer, the governor of New Hampshire, who was an eager reformer of law. But this proved to be disappointing as well, because of disagreement among the common lawyers dominant in the state parliament.

Meanwhile, Bentham also tried to convince the Russian authorities. Between 1813 and 1814, he wrote a letter to Alexander asking for permission to draft a Criminal Code. But as Bentham was on bad terms with Gustav Rosenkampf who was the head of the commission of codification for Russia, his interest moved, in time, from Russia to Poland. In Poland, Bentham had a better chance because he knew Adam Czartoryski who had been expected to become the first viceroy of the restored kingdom of Poland. Between Bentham and Czartoryski, there was an agreement that Bentham would write the Constitutional, Civil and Criminal Codes for Poland. But a person of whom Bentham knew nothing was appointed as the viceroy, and so Bentham's interest in Poland gradually faded away.

In the 1820 s, there emerged many newborn liberal countries in Southern Europe and

\footnotetext{
${ }^{21}$ Legislator of the World (CW), p. 291.

${ }^{22}$ Cf. W. Twining, Globalization and Legal Theory, London, 2000, pp. 94-102.
} 
Latin America, and Bentham tried to make the most of that situation. Firstly, in 1820 he proposed the adoption of his Pannomion to the new Spanish government. He saw that the principle of utility was embodied in the new Spanish Constitution. Although nothing went ahead as to the Pannomion, Bentham's theory became influential in Spain after it was widely introduced by Spanish scholars. He was also deeply concerned with the Greek interim government. Although the chances of introducing the Pannomion were not great in this country either, Bentham made certain contributions to this new government such as commenting on the new Greek constitution and advising the minister of justice, Negris, who was trying to draw up a Civil Code for Greece. Bentham's plan to introduce his Pannomion didn't go well in Latin America either. He had some influence on the regulation of parliament in Buenos Aires, and he accepted a request from José del Valle to help to draw up a Civil Code for Guatemala, but these were his only achievements there. However, Bentham's The Theory of Legislation was used as a textbook in universities of such countries as Chile, Columbia and New Granada.

When we consider Bentham's aspect as a legislator of the world, we cannot ignore what happened in Portugal. In 1821, he offered his Constitutional, Civil and Criminal Codes to the newborn Portuguese government and the Portuguese parliament fully accepted the offer. As I said in the introduction, the Portuguese government was unfortunately overthrown in 1823, but I think it is a remarkable fact that there was a quite high possibility that a legal system independent of Roman law and the common law could have been introduced in nineteenth-century Europe. ${ }^{23}$

\subsection{Bentham and cultural diversity}

One of the criticisms of Bentham's plan to be the legislator of the world may be that he did not consider the historical or social features of each country. But he was certainly aware of the problems of cultural diversity suggested by Montesquieu. In 1811, in a letter to Madison, Bentham describes himself as follows:

Nor, if I may venture to say as much, would it be easy to find any person, more compleatly aware of the demand, presented by the nature of the case, for attention to those local exigencies; nor more compleatly in the habit of looking over the field of law in this particular view. Of this disposition, and this habit,

\footnotetext{
${ }^{23}$ As to the description of this section, $c f$. P. Schofield, Editorial Introduction, Legislator of the World (CW), pp. xilviii.
} 
exemplifications of considerable amplitude may be seen, in the already mentioned work, which for these nine years, has been under the public eye. ${ }^{24}$

In the following, I want to consider how Bentham thought about the problems of cultural diversity by discussing 'Of the Influence of Time and Place in Matters of Legislation', 25 which is substantially identical with the work mentioned by Bentham in the extract above. ${ }^{26}$ In this work, Bentham generally discusses what changes are necessary in the Pannom ion at the time of its transplantation to a country proposing its adoption (in this article Bentham chose Bengal as an example of the country where Pannomion is to be transplanted). It is worthwhile discussing 'Time and Place', because Bentham's general attitude towards differences of customs, cultures and religions of various countries can be made clear. It is also worthwhile discussing it because, as I suggested in the introduction, Bentham's attitude towards cultural diversity may provide us with some useful hints when we discuss problems of law and justice in a global society. This section will be devoted to the introduction and analysis of 'Time and Place' and the order of discussion will follow the organization of Bentham's work.

In the introduction of 'Time and Place', Bentham refers to the methodology of the work:

First, the laws which it is supposed would be the best for England, must be exhibited in terminis: next, the leading principles upon which the differences between those and the laws for Bengal appear to turn, must be displayed: lastly, those principles must be applied to practice, by travelling methodically over the several laws which would require to be altered from what they are in the one case, in order to accommodate them to the other. ${ }^{27}$

The second and the third points are considered by Bentham in chapter 1 of the work, entitled 'Principles to be Followed in Transplanting Laws'. He began by considering the question 'by what principles are the variations necessary to be made in these laws (the best laws for England), in order to accommodate them to the circumstances of Bengal, the country into which they are

\footnotetext{
${ }^{24}$ Legislator of the World $(C W)$, p. 26.

${ }^{25}$ Cf. J. Bentham, 'Of the Influence of Time and Place in Matters of Legislation', The Works of Jeremy Bentham, ed. J. Bowring, 11 vols., New York, 1962, i. pp. 169-94. Hereafter 'Time and Place'.

${ }^{26}$ The work mentioned by Bentham is in The Theory of Legislation (1802). However, I will examine the work in the Bowring edition.

27 'Time and Place', p. 172.
} 
to be transferred, to be determined'. ${ }^{28}$ The answer Bentham gave was a very simple one, which is related to the 'circumstances influencing sensibility'.

As is well known, Bentham cited seven dimensions for calculating pains and pleasures. And of these, the most important are intensity, duration, certainty and propinquity. Bentham thought that duration, certainty and propinquity can be measured precisely. But, according to Bentham, intensity that 'reflects a particular person's response to a particular pleasure or pain' is subjective and cannot be measured precisely. ${ }^{29}$ This is because in the same mind such and such causes of pain or pleasure will produce more pain or pleasure than such or such other causes of pain or pleasure: and this proportion will in different minds be different' ${ }^{30}$ In chapter 6 of IPML, Bentham considers circumstances influencing sensibility such as health, firmness of mind, religious sensibility, age and so on. And he argues that as these circumstances produce biases in each person's sensibility, it happens that the same thing may produce different amounts of pleasure or pain in different persons.

It is interesting to note that Bentham thought that the quality or bias of sensibility is not only different among individuals but also among communities. Bentham's ethics depends solely upon the responses to pleasures and pains of the relevant community. For example, from Bentham's perspective, cocaine use is right for a community where greater pleasures than pains are produced by it (including effects on non-users), and it is wrong for a community where the result is converse. ${ }^{31}$

Bentham recognised the universality of human nature and human needs. In 'Time and Place', he denied that different countries have different catalogues of pleasures and of pains by saying that 'thus far at least, human nature may be pronounced to be everywhere the same'. ${ }^{32}$ According to Bentham, the difference:

lies not in the pains and pleasures themselves, it must lie, if anywhere, in the things that are, or are liable to be, their causes. ... The same event, an event of the same description, nay, even the same individual event, which would produce pain or pleasure in one country, would not produce the same effect of the same sort, or if of the same sort, not in equal degree, in another. ${ }^{33}$

\footnotetext{
${ }^{28}$ Ibid.

${ }^{29}$ T. Warke, 'Classical Utilitarianism and the Methodology of Determinate Choice in Economics and in Ethics', The Journal of Economic Methodology, vii (2000), p. 377.

${ }^{30}$ IPML $(\mathrm{CW})$, p. 51.

${ }^{31}$ This is an example by Warke.

32 'Time and Place', p. 172.

${ }^{33}$ Ibid.
} 
Therefore, in the catalogue of circumstances influencing sensibility, 'we shall find the sum total of the principles of which we are in search: the principles which, in our inquiry concerning the influence of place and time on matters of legislation, are to serve as a guide' ${ }^{34}$ In other words, for instance, where people experience huge pain from crimes which offend religious sensibility, the punishment must be made heavier accordingly. So the legislator should be provided with two tables to do the work required. 'Those of the first set would exhibit a number of particulars relative to the body of laws which has been pitched upon for a standard, as contemplated in different points of view' ${ }^{35}$ And 'Those of the other set will be: a general table of the circumstances influencing sensibility ${ }^{36}$ such as 'tables or short accounts of the moral, religious, sympathetic and antipathetic biases of the people for whose use the alterations are to be made' ${ }^{37}$ After speaking thus, he pursues the third element of the methodology of the work, which applies the principles to practice. He does this by exhibiting the influence of circumstances according to the division of offences in the Pannomion.

The title of the second chapter of 'Time and Place' is 'Regard to be Paid to Subsisting Institutions'. In this chapter, what Bentham did first was to divide the examples of the influence of circumstances into two classes. According to Bentham:

the first class, consisting of those which are physical, in which the influence of circumstance operating as a ground of variation is insurmountable: the other, consisting of those which are moral, in which that influence is not necessarily and absolutely insurmountable. ...To the first class belong the circumstances of climate and the texture of the earth, in as far as the condition of things exterior to man is determined by them. To the other class belong the circumstances of government, religion, and manners including the several primary circumstances, through the intervention of which these secondary ones display their efficacy. ${ }^{38}$

Of the first class of the influence of circumstances, Bentham gives the example that a wound in a hot climate may be much more painful; that a confinement in a hot country may

\footnotetext{
${ }^{34}$ Ibid., p. 173.

${ }^{35}$ Ibid.

${ }^{36}$ Ibid.

${ }^{37} \mathrm{Ibid}$.

${ }^{38}$ Ibid., p. 177.
} 
result in huge pain, and that drunken persons in the south may be more harmful than those in the north. As examples of the second class of the influence of circumstances, he gives the example that confinement of a Hindu may result in serious pain by excluding him from religious ceremonies; that the votary of every sect may receive a cruel wound from any discourse which reflects contempt for the object of his veneration; that imputations of homosexuality may be much more painful in England than in ancient Greece (so that false claims of homosexuality must be punished more heavily in England), and that keeping wives in confinement may be reasonable in Mahometan countries.

It is in his discussion of the second class that Bentham distances himself from Montesquieu. The point of Montesquieu's theory may be that successful legislation must take empirically recognized sociological varieties into account, and Bentham certainly agreed with this. ${ }^{39}$ But Bentham criticizes Montesquieu for not distinguishing what is and what ought to be, by saying that Montesquieu 'appears to have confounded the question of fact with the question of fitness'. ${ }^{40}$ Bentham was fully aware that Montesquieu's idea of 'adjusting laws and institutions to fit given circumstances could and often did have an essentially conservative tendency'. ${ }^{41}$

Thus, according to Bentham, biases of sensibilities caused by governments, religions and customs are not insurmountable and the maintenance of subsisting institutions is not justified a priori. ${ }^{42}$ Then what should legislators do? Bentham says that legislators should consider the following questions. If the model law is superior to the indigenous law, which is likely to be the greater evil, '[t]he evil depending upon such inferiority, or the evil, if any, which might be produced by the measures requisite to remove the other? ${ }^{43}$ This question may be answered as 'the evil of the remedy is, perhaps, likely to be but temporary; while the evil of the diseases, and thence the benefit of the remedy, is likely to be perpetual'. ${ }^{44}$ Then, Bentham says, comes another question. 'What portion of present comfort is it worth-while to sacrifice for the sake of any, and what, chance of future benefit? ${ }^{45}$ To answer these questions is the theme of chapter 3 'Rules Respecting the Method of Transplanting Laws'.

In chapter 3 of 'Time and Place', Bentham posits nine rules with regard to the

\footnotetext{
${ }^{39}$ Cf. J. H. Burns, 'Utilitarianism and Reform: Social Theory and Social Change, 1750-1800', Utilitas, i (1989), p. 212.

40 'Time and Place', p. 180.

${ }^{41}$ Burns, 'Utilitarianism and Reform', p. 213.

${ }^{42}$ Cf. M. Lobban, A History of the Philosophy of Law in the Common Law World, 1600-1900, Dordrecht, 2007, p. 171.

43 'Time and Place', p. 178.

${ }^{44}$ Ibid.

${ }^{45}$ Ibid.
} 
transplantation of law. And of these, the following rules are important.

That 'the clear utility of the law will be as its abstract utility, deduction made of the dissatisfaction and other inconvenience occasioned by $\mathrm{it}^{46}$ is the fifth rule, which is complemented by the sixth rule, 'the value of dissatisfaction will be in the compound ratio of three things: 1 .The multitude of the persons dissatisfied; 2.The intensity of the dissatisfaction in each person; 3.The duration of the dissatisfaction on the part of each' ${ }^{47}$ Here we should consider the concept of intensity in Bentham's theory. As we saw above, intensity cannot be measured precisely because of its subjective character. So how did Bentham try to measure the intensity of dissatisfaction in the above sixth rule? The answer is, through discussion. According to Tom Warke, public choice in Bentham's theory had a twostep utilitarian process:

First, proponents of any action must specify, thus opening to debate, the types of pleasure and pain that they believe will ensue. ... Second, they must specify, again opening to debate, what relative weights on these types of pleasure and pain have led them to their conclusion that the act would add to the aggregate happiness of sentient beings. ${ }^{48}$

In a word, Bentham thought that the intensity of people's pleasure and pain can be understood only through open discussion.

We should also note that Bentham here refers to dissatisfactions occasioned by new laws. What matters here is his disappointment-preventing principle to which I have referred in section 2.1. ${ }^{49}$ Bentham emphasized the importance of utility arising from expectation, and thought that if a legislator tries to reform and change the subsisting institutions, there may rise disutilities derived from the disappointed expectations. The disappointment-preventing principle was supposed to solve this problem by compensating those who lost through reforms.

The seventh rule was that 'as a means of obviating dissatisfaction, indirect legislation should be preferred to direct; gentle means, to violent: example, instruction, and exhortation should precede or follow, or, if possible, stand in the place of law'. 50

Bentham summarizes his argument of this chapter as follows:

\footnotetext{
${ }^{46}$ Ibid., p. 181.

47 Ibid.

${ }^{48}$ Warke, p. 378.

${ }^{49}$ As to this principle, $c f$. Kelly, Distributive Justice, ch. 7.

50 'Time and Place', pp. 181-82.
} 
The general result of these rules is, that the legislator, in producing great changes, ought to be calm, collected, and temperate in well doing ... indemnifying those that lose, and making an alliance, so to speak, with time. ${ }^{51}$

That calculations of utilities are required at the transplanting of laws, that indirect legislation which does not give rise to antipathies is preferred and that disappointment caused by the reform must be compensated through the disappointment-preventing principle are the main points of Bentham's argument. And for our purpose, it is important to note that Bentham thought that calculation of utility should be done directly through open discussion.

Freedom of the press and of public discussion has a critical role in Bentham's theory. As we have just seen, Bentham thought that what makes people happy should be decided by calculating the intensities of pleasure and pain felt by them. Here lies the importance of public discussion, which was a means to determine the intensity of experience, and freedom of the press, which provided materials for the discussion. Of course, these devices were also important for despotic countries. Bentham thought that a people restricted by a heap of idle, trifling, and ridiculous obligations and restraints were by no means happy and argued that the mere whim of a despot could not decide the utility of an institution. ${ }^{52}$ He seems to argue that even despots should consult people's intensity of response to their proposals through a free press and free public discussion in order to carry out policies which lead to the greatest happiness of the greatest number. In section 3, I will examine Bentham's attitude toward despots through his work 'Securities Against Misrule', which is, I think, attempting to address the problems caused by cultural pluralism.

\section{Bentham's 'Securities Against Misrule'}

\subsection{Bentham on tyranny}

Bentham's attitude toward despots is developed in one of the volumes in the Collected Works of Jeremy Bentham, Securities Against Misrule and other Constitutional Writings for Tripoli and Greece. ${ }^{53}$ This work includes 'Account of Tripoli', 'Securities Against Misrule' and 'Letters to John Quincy Adams' which were mainly written in 1822. And 'Securities Against Misrule' is

\footnotetext{
${ }^{51}$ Ibid., p. 184.

${ }^{52}$ Cf.ibid., p. 192.

${ }^{53}$ Cf. J. Bentham, Securities Against Misrule and other Constitutional Writings for Tripoli and Greece, ed. P. Schofield, Oxford, 1990 (The Colected Works of Jeremy Bentham). Hereafter SAM $(C W)$.
} 
divided into ‘Constitutional Securities of Tripolitan Nation' and 'Preliminary Examinations'.

Bentham's interest in Tripoli derived from his close friendship with Hassuna D'Ghies who was a diplomat and a member of a leading Tripolitan family. Bentham and D'Ghies first met in 1822 when Bentham received a favorable response from Portugal to his proposal to draft his Pannomion for that country and was eager to pursue this opportunity.

The region, referred to as barbarian at this time, was unstable and poor. According to Bentham, the major problem was social and political instability. And the Pasha's arbitrary power and the absence of a rule of succession were the main reasons for that instability. For this situation, Bentham proposed constitutional reforms: the introduction of a constitutional charter of his own writing that limited the arbitrary power of the Pasha, and the establishment of a representative government. Bentham argued that these devices were also good for the rulers because they would create stability and the economic growth which, Bentham thought, would result from that stability. ${ }^{54}$

In this section, I will introduce the articles in Securities Against Misrule and other Constitutional Writings for Tripoli and Greece in the following order. In 'Account of Tripoli', Bentham develops studies of the geographic, historical, social and political circumstances of Tripoli. It can perhaps be regarded as Bentham's other work on legal and social studies, standing beside 'Time and Place'. 'Preliminary Examinations' concerns a rationale for the provisions of the constitutional charter and 'Constitutional Securities' consists of the constitutional charter itself. And we can see how Bentham tried to accomplish constitutional reform in Tripoli by examining 'Letters to John Quincy Adams' (which I will discuss in my conclusion.)

As the author of 'Time and Place', Bentham was well aware of the importance of differences of customs, cultures and religions of various countries when transplanting his Pannomion. In 'Account of Tripoli', he focuses on the judicial and religious establishments of that country and tries to use these establishments for his constitutional reform rather than modifying them. As to the judicial establishment, Bentham firstly refers to the Cadi, or minister of justice, one of whom sits in each of nine districts of the country. According to Bentham, to the logical field of the Cadi's jurisdiction, 'there are no limits. It embraces all causes, civil, penal, and religious' ${ }^{55}$ Bentham also refers to the Mufti, who has exclusive rights of interpretation of the law and helps the Cadi. As to the religious establishment, Bentham says that there are 3,000 mosques in the country and that 'of the whole territory of the State there is

\footnotetext{
${ }^{54} C f$. P. Schofield, Editorial Introduction, $S A M(C W)$, p. xxi.

${ }^{55} \operatorname{SAM}(C W)$, p. 9.
} 
not any part that is not included in the field of authority belonging to some Mosque'. ${ }^{56}$ Bentham tried to use these establishments to make his constitutional charter effective. We will see the details of Bentham's plan in what follows.

In the second section of 'Accounts of Tripoli', Bentham describes the chief of the state, the Pasha (Bashaw). After depicting the completely arbitrary nature of the Pasha's power and the problems arising from it, which for the purposes of this discussion I will refer to as social instability, Bentham says:

The succession is regarded hereditary in the present family. But the order of succession as between son and son is not regarded as settled. How general a gloom is cast over the whole country by this uncertainty may be imagined. The seating of the present Bashaw on the throne was the civil war between brother and brother: and upon his death, unless in the mean time some effectual remedy be applied, another civil war is regarded as inevitable. ${ }^{57}$

For the purposes of this discussion, I will refer to these wars of succession as political instability. The remedy for the social instability is the introduction of a constitutional charter; and the remedy for the political instability is representative government. The details of these remedies are developed in 'Securities Against Misrule'.

As I wrote earlier in this section, 'Securities Against Misrule' is divided into 'Constitutional Securities of Tripolitan Nation' and 'Preliminary Examinations'. First, I examine the rationale of the constitutional charter developed in 'Preliminary Examinations'. In that work, Bentham examines the remedy for social instability arising from the Pasha's arbitrary power. First he divides the shapes of misrule as follows:

1. Shape 1. Sufferers all determinate: the individuals all determinate and assignable. Examples: Homicide, Confinement, Banishment. In the aggregate of this suffering consists the evil of the first order: for distinction sake it may be called purely private.

2. Shape 2. Sufferers, altogether undeterminate. Examples: Waste of public money: Act of engaging in unnecessary war. In this case the evil may be called purely public.

\footnotetext{
${ }^{56}$ Ibid., p. 12.

${ }^{57}$ Ibid., p. 6.
} 
3. Shape 3. Immediate sufferers determinate, but the greater part of the evil composed of the sufferings of individuals altogether undeterminate. Examples: 1. Political gagging: i.e. obstructing in any way the communication between mind and mind for the melioration of the common lot on any subject of discourse: more especially on a political subject. 2 . National debilitation: weakening the means of defence and security in the hands of the people against injury at whatsoever other hands, those rulers themselves not expected. In this case the evil may be said to be mixt; or public through the medium of private. ${ }^{58}$

According to Bentham, the remedy for these misrules arising from the arbitrary power of Pasha is publicity:

So much for the disease. Now as to the remedy. A single word, publicity, has been employed for the designation of it. For this purpose another expression-Public Opinion-might have been employed. ${ }^{59}$

Bentham argued that publicity is important for stopping misrule because:

the greater the number of the members of the whole community to whom the existence of an act of oppression has been made known, the greater is the number of those by whom, on the occasion of an endeavour to exercise other acts of a similar nature, supposing the past act notified to them, not only may obedience withholden, but resistance opposed. ${ }^{60}$

To make this function of publicity work, Bentham developed the concept of a public opinion tribunal, which we will see in the next section.

However, it is not clear why the Pasha should adopt the constitutional charter and give publicity to acts of misrule, which would certainly reduce his power. According to Bentham, the main problem in Tripoli was that:

\footnotetext{
${ }^{58}$ Ibid., p. 26

${ }^{59}$ Ibid., p. 27.

${ }^{60}$ Ibid., p. 30.
} 
Neither for life nor for liberty, for neither of those possessions, against resentment, fear, concupiscence or erroneous conception in the breast of Sovereign, can any permanent security be possessed by any one individual in the community in the present state of the government.

In respect of property all labour under insecurity, not merely in that shape in which it involves danger and alarm in respect of what they have already, but in that shape likewise in which by the sense of it they are prevented from making all those additions to it to which a feeling of security such as is enjoyed even in the worst-governed European nation is sufficient to give birth. ${ }^{61}$

Bentham also says:

The Pasha's revenue consists in the whole or in great part in a tax on the produce of the soil. Such produce can never receive any considerable encrease, but from a proportionate encrease in the quantity of labour and money laid out upon it in the shape of capital: and the quantity of capital can never receive any considerable encrease but from a correspondent change in the constitution. ${ }^{62}$

In a word, Bentham thought that the Pasha would profit from a constitutional charter because it would increase security and make the country more abundant. Thus, while in 'Time and Place', freedom of the press and of public discussion was a means of revealing the intensities of people's pleasures or pains, in 'Securities Against Misrule', publicity was for security.

As to political instability arising from the absence of a rule of succession, Bentham's remedy was the introduction of representative democracy. Bentham says that if the Pasha wants to avoid dispute about succession to the sovereignty among his sons and danger to the whole nation from a civil war produced by that dispute, he should have a meeting of persons chosen by the people to ratify his choice of successor beforehand. ${ }^{63}$ We will see Bentham's concept of democracy in section 3.3.

\subsection{Bentham's public opinion tribunal}

\footnotetext{
${ }^{61}$ Ibid., pp.108-9.

${ }^{62}$ Ibid., p. 110.

${ }^{63}$ Cf. ibid., p. 109.
} 
In this section, I will examine Bentham's concept of the public opinion tribunal. As we saw above, Bentham argued that misrule could be prevented only through publicity, and the public opinion tribunal played the central part in it. In Bentham's own words, public opinion is 'the only source which is not included in the force of government: the only force therefore from which the force of government when operating in a sinister direction can experience any the least impediment to its course ${ }^{6}{ }^{6}$

This public opinion tribunal is one of the key concepts of Bentham's theory. It plays a central part in his theory of international law as well. As this article mainly concerns Bentham's idea of law and justice in a global society, it is important for us to understand this concept properly.

As to the constitution of the tribunal, Bentham says the following:

The persons considered as members of this tribunal are an indeterminate portion of the whole number of those of whom the community in question is composed. Those by whom actual cognizance is taken of the matter in question in the first instance may be considered as a Committee: those who in consequence of the opinions expressed by this same Committee, but without taking actual and particular cognizance of the circumstances of the case, join with them at different times in the same opinions, affections, wishes, designs and endeavours, constitute the body at large of which the smaller body abovementioned is the Committee. Of the Members of this larger body, the number may be of any magnitude not exceeding the sum total of the adequately adult members of the community. ${ }^{65}$

And as to the function of public opinion tribunal, Bentham says it has mainly a statistic or evidence-furnishing function (delivering information and evidence of misrule), a censorial function (rendering judgments) and an executive function (punishing and rewarding). ${ }^{66}$ And in these, the newspaper has a leading role:

In a Representative Government, at any rate in a Representative Democracy, with the exception of the function of the principal Minister, greater is the

\footnotetext{
${ }^{64}$ Ibid.,p. 121.

${ }^{65}$ Ibid.

${ }^{66}$ Cf. J. Bentham, Constitutional Code, ed. F. Rosen and J. H. Burns, Oxford, 1983 (CW), pp. 37-9.
} 
importance of the function of this unofficial functionary than of any official one: more important, that is to say particularly to the greater purpose here in question that of making application of the power of the Public Opinion Tribunal in by far the most beneficial and the highest character of a check against misrule. By the Prime Minister impulse is given to the machinery of the political sanction: by the editor of the prime popular Newspaper, to that of the social sanction. ${ }^{67}$

To be more specific, newspapers deliver information concerning misrule among the people and examine and criticize the misrule. Then people put their judgment into effect through social sanctions which include:

all obstructions to the exaction of taxes the produce of which is at the disposal of the sovereign: all obstructions capable of being opposed to the execution of the judgment of the several regularly constituted judicatories: all modes of annoyances by which, in retribution for the demonstration of hatred contempt are rendered: invectives said and sung: invectives written and posted up: of whatsoever liberty is left to the citizens, to the members of the community at large, by the laws and practice of the government, use made to the purpose of opposing and as far as may be frustrating those same laws and that same practice. $^{68}$

Ultimately, Bentham included in the social sanction the withdrawal of all obedience to the power of the sovereign.

Bentham tried to introduce the public opinion tribunal in Tripoli and he argued that even despots including the Pasha of Tripoli should admit freedom of the press and of public discussion. According to Bentham, in Tripoli the main subjects of publicity were ordinances and the transgression of ordinances. The ordinances mean, of course, the constitutional charter, which Bentham devised. And the contents of the constitutional charter developed in 'Constitutional Securities of Tripolitan Nation' are divided into securities in favour of the nation and those in favour of individuals. The former comprise mainly security against vexation on account of religion and security for appeal to public opinion. And the latter comprise mainly securities against secret confinement, injurious banishment, secret and

\footnotetext{
${ }^{67}$ SAM $(C W)$, pp. 45-6.

${ }^{68}$ Ibid., p. 124.
} 
unlawful homicide, misuse of private writings, official oppression and so on. These and the transgression of them were to be delivered among the people of Tripoli who would in the end punish the conductors of misrule through the social sanction we saw above.

By the way, Bentham acknowledged the difficulty of using newspapers to deliver information on the constitutional charter and the transgression of it in Tripoli:

The power of public opinion being the only check that can be applied to the power of the arbitrary government, and the efficiency of that tutelary power depending as above upon the numbers of the persons to whom on each occasion the appropriate information is notified, the great misfortune is that in the country in question the means of notification are so narrow: in that country free Newspapers the matchless instruments of notification even Newspapers of every kind being as yet altogether wanting. ${ }^{69}$

So Bentham tried to use the two universities, the 14 judicatories and the 3,000 mosques for the purpose of notification. He also tried to use the Cadi or Iman which he referred to in 'Account of Tripoli' for the purpose of punishment for violation of the constitutional charter.

\subsection{Bentham on democracy and international law}

In the previous two sections, we saw Bentham's argument regarding despots through an examination of his work 'Securities Against Misrule'. Bentham argued that even despots should adopt the public opinion tribunal. He argued that this scheme is good for despots as well because it would, he thought, lead to prosperity by introducing security.

However, Bentham later changed his position. In a word, he realized that it is illusionary to expect despots to adopt his scheme of reform. This point is concerned with Bentham's theory of democracy.

There are, I think, three turning points in Bentham's attitude toward democracy. The first was from 1788 to 1792 when Bentham temporarily became a democrat at the time of the French Revolution. But at that time he only argued that a democratic regime should be introduced in France, because of the Bourbon regime's severe problems, and he didn't regard democracy as being universally desirable. Actually, in 1792, after the turmoil of the French Revolution, Bentham became critical of democracy itself.

${ }^{69}$ Ibid., p. 129. 
The second turning point was from 1809 to 1810 when he 'fully' became a democrat. After the failure of Scottish law reform and a meeting with James Mill, Bentham became a philosophical radical and began to argue that a full representative democracy was necessary to accomplish the greatest happiness of the greatest number in Britain. However, he didn't become a 'universal democrat' at this time either. He thought that democracy was good for Britain, but also that forms of regime should be relevant to the time and place of countries. This point is easily understood from his work 'Securities Against Misrule', which we saw above. There he proposed, at first, that despots should adopt his constitutional charter, which is compatible with an undemocratic regime.

For our purpose, the third turning point is the most important. When he wrote the article 'Economy as applied to Office' in 1822, he finally set out his position that only representative democracy can accomplish the greatest happiness of the greatest number. From then on, his proposal to draft the Pannom ion concentrated mainly on liberal countries such as Spain, Portugal, Greece and Latin America. ${ }^{70}$

We have just seen Bentham's change of attitude toward democracy. As to the public opinion tribunal, it was firstly thought to be universal. But, in the end, here again, Bentham seems to give up his idea that a despot (like a Pasha of Tripoli) would adopt the public opinion tribunal. Bentham stopped thinking that he could convince the Pasha that a public opinion tribunal would be of benefit to him, and began to endorse a more controversial plan of military intervention. We will see this controversial plan in the conclusion. Before that, though, I want to examine very briefly Bentham's plan regarding international law, in which the public opinion tribunal plays an important role.

It is well known that Bentham invented the phrase 'international law'. For Bentham, it was important to secure definitions of the rights and obligations of nations. This, Bentham thought, would help to avoid conflicts arising from misunderstandings over rights. As to the sanctioning authority, Bentham firstly thought that a code of international law should be approved, adopted and sanctioned by a confederation of states meeting at an international congress. He also wrote that it is necessary to establish a common court of judicature whose judge is elected by the congress. This court later became the central concept in Bentham's theory of international law. As to the enforcement of the judgment of this court, Bentham at first considered military intervention but he later considered this inconsistent with national

\footnotetext{
${ }^{70}$ But according to Philip Schofield, the third turning point was 1817. Cf. P. Schofield, 'Jeremy Bentham: Legislator of the World', Current Legal Problems, li (1998), p. 146.
} 
sovereignty. Here again, the public opinion tribunal plays an important role. ${ }^{71}$

According to Steven Conway, for Bentham:

publicity was ... meant to be the weapon employed against recalcitrant governments. Once the soundly based decisions of court became widely known, governments that remained defiant would be exposed to a pressure that Bentham believed to be far more effective than military coercion. They would have to account for their actions to the Public Opinion Tribunal, composed of all the several individuals belonging to all the several states. ${ }^{72}$

For this purpose, Bentham argued that freedom of the press is necessary in every country. The public opinion tribunal is important for international securities as well.

\section{Conclusion}

In this article, I have discussed Bentham as 'the legislator of the world'. In section 2, I examined Bentham's work 'Of the Influence of Time and Place in Matters of Legislation' and tried to depict his attitude toward cultural diversity. In section 3, the main subjects were articles from SecuritiesAgainst Misrule and other Constitutional Writings for Tripoli and Greece. There, I examined Bentham's attitude towards tyrannies and his concept of the public opinion tribunal, which plays an important part in his theory of international law as well.

Now, I want to examine Bentham on law and justice in a global society. There are, I think, many ways to discuss this. But I want to concentrate on the themes to which I referred in the introduction. The first is Bentham's attitude toward cultural diversity, or, I should say, Bentham's awareness of the defects of globalization. As I said in the introduction, both globalization and cultural pluralism are problematic in our age. And the main problem with globalization is that it doesn't pay enough attention to the social systems, cultures and religions of different countries. Bentham's position towards cultural diversity is, I think, instructive even today because it seems to avoid the defects of globalization by emphasizing what may be called the preferences of the people of the world. In other words, the autonomy of the people of the world was most important in Bentham's attitude towards cultural diversity. In the following, I want to examine this aspect of Bentham by comparing it with John Locke's and John Stuart Mill's

\footnotetext{
${ }^{71}$ Cf.S.Conway, 'Bentham on Peace and War', Utiitas , i (1989), 98.

${ }^{72} \mathrm{Ibid}$. This argument is challenged by Gunhild Hoogensen who argues that public opinion is not so important in Bentham's international law theory as many commentators think. Cf. G. Hoogensen, International Relations, Security and Jeremy Bentham, London, 2005.
} 
attitudes towards cultural diversity.

As we saw in section 2, Bentham, who aspired to be the legislator of the world, considered what alterations would be necessary for his Pannom ion to be appropriate to the circumstances of each country.

Firstly, he thought that the principle guiding the transplantation of laws from one region to another was concerned with the circumstances influencing sensibility. In other words, he argued that legislators who transplant the law must consider the biases of sensibility, which Bentham thought differed between communities. He then divided these into physical ones and moral ones, and argued that the latter can be changed. Because of the existence of expectation utility, Bentham thought that some regard must be paid to subsisting institutions. But he also argued that institutions at odds with the principle of utility, such as tyrannies or religious oppressions, must be reformed.

The distinctive point of Bentham's attitude towards cultural diversity was, as I said earlier, his emphasis on the autonomy of the people of the reformed countries. If despots promoted freedom of the press and of public discussion, people would, Bentham thought, choose his Pannomion as realizing their best interests and eschew biases at odds with the principle of utility, such as a religious bias. This distinctive point of Bentham's attitude can be made clear by comparing it with those of Locke and Mill.

As to Locke's attitude towards cultural diversity, Barbara Arneil's work, which considers the influence of Locke's theory on Amerindians, provides useful insights. In her book, John Locke and America, Arneil suggests that there are two fundamental aspects in Locke's argument regarding property. The first, she says, is Locke's belief that it is the natural right of labour which begins property. Discovery and occupation, having stood as the foundation of property in natural law for centuries, were no longer sufficient' so that 'aboriginal lands which were occupied but uncultivated could also be appropriated by Englishmen who were willing to labour on them'. ${ }^{73}$ And secondly, she continues, 'Locke's definition of labour was very specifically agrarian. The founding of property in land was that of the Englishman, enclosing and cultivating the soil. Amerindians who chose not to follow the European forms of labour thereby relinquished any claim they may potentially have had to the land'. ${ }^{74}$ According toArneil, 'these two fundamental aspects of Locke's argument regarding property ... were indeed used to justify both the appropriation of land by the English

\footnotetext{
${ }^{73}$ B. Arneil, John Locke and America: The Defence of English Colonialism, Oxford, 1996, pp. 206-7.

${ }^{74}$ Ibid., p. 207.
} 
and the conversion of Amerindians to agrarian labour. ${ }^{, 75}$

As is well known, the central element of Mill's theory was autonomy, which is reflected in his harm principle. Mill's strategy was to promote human perfection by protecting autonomy or liberty from any coercive intervention. But on the other hand, Mill says that:

Despotism is a legitimate mode of government in dealing with barbarians, provided the end be their improvement, and the means justified by actually effecting that end. Liberty, as a principle, has no application to any state of things anterior to the time when mankind have become capable of being improved by free and equal discussion. Until then, there is nothing for them but implicit obedience to an Akbar or a Charlemagne, if they are so fortunate as to find one. ${ }^{76}$

This aspect of Mill is fully developed in Michael Levin's recent book, J.S. Mill on Civilization and Barbarism, which concentrates on Mill's relationship with India. I don't have enough space to examine Levin's theses fully here, but the nutshell of his argument on Mill is, I think:

The Indian people were not yet fit recipients of liberty, which would become their due only at a later stage of development. In June 1852, Mill had informed a House of Lords committee that the public of India afford no assistance in their government. They are not ripe for doing so by means of representative government. Only occasionally had reform come from within to a barbarian people. Finding an Akbar or a Charlemagne is 'fortunate' not because it dispenses with despotism, but because it uses it to achieve some primary steps of development. $^{77}$

Now I think the distinct point of Bentham's attitude towards cultural diversity has become quite clear. Firstly, the most remarkable point in the comparison of Locke and Bentham is that the coercion of natural law is absent from Bentham's theory. What Bentham tried to do was to persuade foreigners to adopt his Pannom ion. On the other hand, Mill's paternalism is also absent. Bentham thought that people themselves would choose the Pannom

\footnotetext{
75 Ibid.

${ }^{76}$ J. S. Mill, 'On Liberty’, Utilitarianism, On Liberty, Considerations on Representative Government, ed. G. Williams, London, 1993, p. 79.

${ }^{77}$ M. Levin, J.S. Mill on Civilization and Barbarism, London, 2004, p. 46.
} 
ion if they were fully enlightened. According to Jennifer Pitts, there weren't any imperialistic elements in Bentham's theory. ${ }^{78}$ From these remarks, it can be rightly said that 'Bentham's belief that each individual is the best judge of his or her own interest, and should be provided with the fullest opportunities to promote it accordingly' is reflected in his attitude toward cultural diversity. ${ }^{79}$

Bentham's position in relation to cultural diversity is also clarified by the nature of his principle of utility. It is generally thought that Bentham's principle of utility was a critical or abstract one. But Rosen argues that 'like Hume, ... Bentham seems to have argued that one can appeal to the positive standard of a convention but not to an abstract, critical standard' and emphasizes the empirical or conventional nature of Bentham's principle of utility. ${ }^{80}$ And Rosen's argument can be confirmed by 'Time and Place' where Bentham argued that what makes the greatest happiness of the greatest number should be decided by public discussion. Although Bentham's Pannomion was based on the principle of utility, it was the people of each country who decided whether it leads to their happiness or not. But we must also be aware of the difference between Bentham and Hume, who justified subsisting institutions as embodying utility. As we saw already, Bentham was aware of the possibility that people did not have enough knowledge to judge their best interests and tried to enlighten those people by introducing freedom of the press and of public discussion.

In the introduction, I stated the problem of cultural pluralism - namely, that responding to the problems of modern society such as tyrannies and religious oppressions is difficult from the perspective of cultural pluralism. As we saw above, Bentham's own position was that biases of sensibility arising from tyrannies or religious oppressions should be reformed because every social institution must be based on the intensities of people's pleasures and pains. Bentham first thought that even a despot would willingly adopt his scheme of the public opinion tribunal because it was good for the despot as well. But in 1822, he changed his position and endorsed a controversial plan of military intervention.

In 'Letters to John Quincy Adams', which is in Securities Against Misrule and Other Constitutional Writings for Tripoli and Greece, Bentham develops the strategy of how to introduce his reforming scheme into Tripoli. He was quite optimistic:

Tripoli would be the country for the Revolution to take its commencement. In

\footnotetext{
${ }^{78}$ J. Pitts, 'Legislator of the World? A Rereading of Bentham on Colonies', Political Theory, xxxi (2003).

${ }^{79}$ P. Schofield, 'Political and Religious Radicalism in the Thought of Jeremy Bentham', History of Political Thought, Xx (1999), p. 276.

${ }^{80}$ F. Rosen, Introduction, IPML $(C W)$, p. lvii.
} 
that country, there exists not any regular trained or paid armed force whatever. Not so much as a body-guard in the condition of a standing army has the sovereign of the state. ... The despotism continues because no man, with hundred others to stick by him, has ever been found to stand up and propose any thing better.

Could they but rely on their chief and on each other, the hundred men with whom our Henry 7th. commenced his standing army, or even the fifty men with whom Pisistratus set up his tyranny, would suffice for establishing a popular constitution. $^{81}$

But later, he proposed another method as his main device, setting a model and inspiring the people of other countries. By the way, as I showed in section 3, Bentham argued that introducing a constitutional charter or a representative democracy was not only necessary for respecting the intensities of peoples' pleasures or pains, it was also necessary for introducing security. A leading utilitarian, Peter Singer, restates this point in our time:

Democracy, in the sense of rule of the majority, does not guarantee that human rights will be respected. But a democratic process requires that the policies of the government must be publicly defended and justified. They cannot simply be implemented from above. Although some of us may have the capacity to commit terrible crimes, many of us also have a moral sense, that is, a capacity to reflect on the rights and wrongs of what we are doing, or what our rulers are doing. That capacity emerges in the public arena. A small group may plot genocide, and inspire or terrify their followers to carry it out, but if genocide has to be defended on primetime television, it will become rare indeed. ${ }^{82}$

But then Singer faces 'the ultimate question of the relationship between democracy and sovereignty'. ${ }^{83}$ Here, Singer asks himself 'how can we give reasons independent of our culture, for the view that legitimacy requires popular support, rather than resting on, say, religious law'. ${ }^{84}$ Certainly from some standpoints of 'multiculturalism', illiberal or undemocratic societies, which do not respect the freedom of the press or of public discussion,

\footnotetext{
${ }^{81} \operatorname{SAM}(\mathrm{CW})$, pp. $145-6$.

${ }^{82}$ P. Singer, One World: The Ethics of Globalization, New Heaven and London, 2002, pp. 136-7.

${ }^{83}$ Ibid., p.143.

${ }^{84}$ Ibid.
} 
cannot be denied unless they invade another society. This point bothers other theorists as well. For example, Rawls argues that some human rights such as 'the right to life and security, to personal property, and the elements of the rule of law, as well as the right to certain liberty of conscience and freedom of association, and the right to emigration' are universal and express the minimal standard of his law of peoples. ${ }^{85}$ And Rawls shows that his argument is dependent on the universal (culturally independent) postulation that 'a society's system of law must be such as to impose moral duties and obligations on all its members and be regulated by what judges and other officials reasonably and sincerely believe is a common good conception of justice'. ${ }^{86}$ Although Rawls distances himself from Locke, I think, it can still be argued that Rawls's above postulation is intuitive or reflects his conviction based on the western liberal tradition. As to his concept of the law of peoples, Rawls says that:

I believe that in a society of liberal and decent peoples the Laws of Peoples would be honored, if not all the time, then most of the time, so that it would be recognized as governing the relationship among them. ... Liberal democratic and decent peoples are likely to follow the Law of Peoples among themselves. $^{87}$

Rawls's concept of the law of peoples, including his postulation, is, as suggested by himself, dependent upon his intuition, conviction or belief.

On the other hand, Bentham's position that security is a universal value regardless of time and place has a more solid foundation. In Bentham's theory, security is 'maximized by limiting the possibilities of oppression either by one citizen over another or by the government over the citizen'. ${ }^{88}$ And as we have seen, the former securities are established by the Pannom ion and the latter by the public opinion tribunal and democracy. Bentham was quite sound in arguing that although people are chasing various goods, everyone in the world wants security and security is a necessary value for everyone's life. And these are the reasons for Bentham trying to disperse his Pannomion and the public opinion tribunal, and later democracy, all over the world. I think it is quite difficult to refute Bentham's postulation on security. At least, Bentham's position is far more culturally independent than Rawls's. As John Stuart Mill

\footnotetext{
${ }^{85}$ J. Rawls, 'The Law of Peoples' in On Human Rights, eds. S. Shute and S. Hurley, New York, 1993, p. 68.

${ }^{86} \mathrm{Ibid}$.

${ }^{87}$ J. Rawls, The Law of Peoples, Cambridge, Mass., 1999, p. 125 (emphasis added).

${ }^{88}$ F. Rosen, Jeremy Bentham and the Representative Democracy, Oxford, 1983, p. 75.
} 
argues, security is:

to every one's feelings the most vital of all interests. Nearly all other earthly benefits are needed by one person, not needed by another; and many of them can, if necessary, be cheerfully foregone, or replaced by something else; but security no human being can possibly do without; on it we depend for all our immunity from evil, and for the whole value of all and every good. ${ }^{89}$

Singer's 'ultimate question of the relationship between democracy and sovereignty', which seems to be a cultural question, can be replaced by an empirical question whether freedom of the press, free public discussion and democracy lead to more security. As far as 'Time and Place' and 'Securities Against Misrule' are concerned, Bentham certainly thought that they do.

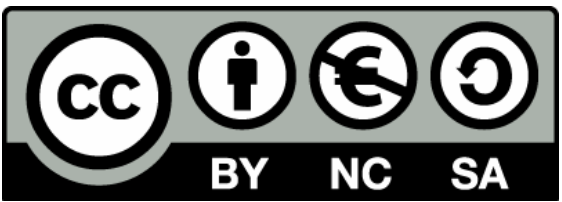

This work is licensed under the Creative Commons Attribution-NonCommercial-ShareAlike 3.0 Unported License. The license allows you to copy, distribute, and transmit the work, as well as adapting it. However, you must attribute the work to the author (but not in any way that suggests that they endorse you or your use of the work), and cannot use the work for commercial purposes without prior permission of the author. If you alter or build upon this work, you can distribute the resulting work only under the same or similar license to this one. To view a copy of this license, visit http://creativecommons.org/licenses/by-nc-sa/3.0/ or send a letter to Creative Commons, 444 Castro Street, Suite 900, Mountain View, California, 94041, USA.

\footnotetext{
${ }^{89}$ J. S. Mill, 'Utilitarianism', p. 56.
} 